\title{
REGOS NERVO UŽDEGIMAS IR SĄSAJOS SU STAT4
}

\author{
Gabrielè Dubinskaitė ${ }^{1}$, Rasa Liutkevičiené⿱2 \\ ${ }^{1}$ Lietuvos sveikatos mokslu universitetas, Medicinos akademija, \\ ${ }^{2}$ Lietuvos sveikatos mokslu universiteto Medicinos akademija, Neuromokslu institutas, \\ Akiu ligu klinika
}

Raktažodžiai: regos nervas, etiologija, klinika, diagnostika, gydymas, STAT4.

\begin{abstract}
Santrauka
Regos nervas - baltosios smegenų medžiagos struktūra, kuri jungia smegenis su tinklaine ir atlieka regimosios informacijos perdavimo funkciją. Anatomiškai šią struktūrą galima suskirstyti i 4 segmentus: akinị, akiduobinị, kaukolès děžèje esančią dalị ir kaulo kanale esančią nervo dali. Neretai regos nervas veikiamas ịvairių aplinkos bei genetinių veiksnių, kurie gali turèti ịtakos regos nervo uždegimo atsiradimui. Bene geriausiai žinomas ir dažniausiai tipinị uždegimą sukeliantis veiksnys yra išsètinè sklerozè, kai atipinis uždegimas siejamas su kitomis būklèmis, tokiomis kaip infekcijos, autoimuninès ligos, toksinès, maistinès ar vaistų sukeltos neuropatijos. Pastaruoju metu kyla nemažai klausimų, kokios yra genetinès priežastys, galinčios daryti įtaką regos nervo uždegimo pasireiškimui, kadangi genetinių veiksnių poveikis vis dar išlieka nepakankamai aiškus.

Straipsnyje apžvelgiama regos nervo neurito etiologija, klinika, diagnostikos ir gydymo galimybės bei STAT4 geno poveikis regos nervo uždegimo pasireiškimui.
\end{abstract}

\section{Ivadas}

Regos nervas (nervus opticus) priklauso galviniams nervams, numeruojamas II romėnišku skaičiumi, atsakingas už regimosios informacijos perdavimą. Tai smegenų su tinklaine jungiančioji grandis, sudaryta iš tinklainès ganglinių ląstelių skaidulų, kurios orbitos ertmę palieka per regos kanalą. Regos nervą gaubia visi galvos smegenų dangalai: kietasis, švelnusis ir voratinklinis, o pats nervas dar skiriamas į 4 dalis $[1,2]$.

Viena dažniausiai su optiniu nervu susijusių patologijų yra optinis neuritas (ON). ON yra dažna darbingų žmonių (18-45 metų amžiaus) liga, kurios 1-5 atvejai tenka 100000 gyventojų [3]. Patologija neretai gretinama su išsètine skleroze (IS) ar kitais infekciniais bei autoimuniniais procesais, tad liga pagal priežastis dar gali būti skirstoma ị du tipus tipinį ir atipinị ON [4].

Greitas ligos diagnozavimas, tinkami instrumentiniai tyrimai ir ankstyvas gydymas lemia kovos su liga sékmę. Ypač svarbią diagnostinę vertę turi instrumentiniai tyrimai, padedantys diferencijuoti ON nuo daugelio kitų, su akies organu siejamų, ligų [6]. Tyrimų pagalba išsiaiškinus tikslią ligos priežastį, remiantis etiologija, taikomas tikslingas gydymas. ON gydymo gairès vadovaujasi atliktais moksliniai tyrimais, irodančiais efektyviausias priemones, skirtas specifiniam ON tipo gydymui nustatyti [13].

Nepaisant jau žinomų regos nervo uždegimo patologiją sukeliančių priežasčių, jų diagnostikos būdų bei tinkamų gydymo gairių, genetinè šios ligos predispozicija nèra visiškai aiški. Vis dažniau aptinkama atliktų tyrimų duomenų apie transkripcijos signalo keitiklių ir aktyvintojų (STAT) baltymų šeimos narių itaką įvairioms autoimuninems ligoms. Mūsų nagrinejjimas objektas STAT4, kuris, kaip ir kiti STAT šeimos nariai, yra atsakingas už daugiafunkcinị fiziologinių ląstelių procesų ir imuninès sistemos reguliavimą [15]. Šiuose procesuose, kaip ir visose organizmo sistemose, gali atsirasti pažeidimų, sąlygojančių netinkamą STAT raišką ir patologinius procesus, pvz. piktybinès ląstelių transformacijos ir metastazès [16].

Tyrimo tikslas - aptarti regos nervo uždegimo etiologiją, kliniką, diagnostikos, gydymo galimybes bei apžvelgti galimas STAT4 sąsajas su regos nervo neurito pasireiškimu.

\section{Tyrimo medžiaga ir metodai}

Informacinès medžiagos ieškota elektroninèje duomenų bazèje Medline (Pubmed), naudojantis raktiniais žodžiais, jų grupèmis bei juos kombinuojant.

\section{Tyrimo rezultatai ir jų aptarimas}

Etiologija. Regos nervo uždegimas yra dažna suaugusiųų ūminio regos nervo pažeidimo priežastis, retai nustatoma vaikams. Tipiškai siejamas su išsètine skleroze (IS), regos nervo neurito priežastimi gali būti ir uždegiminiai 
procesai. Gerai žinomos ir ištirtos regos nervo uždegimo priežastys: autoimuninès ligos, infekcijos, granuliomatozinès ligos, paraneoplastiniai sutrikimai ir demielinizacija. ON prognozè ir gydymas skirsis priklausomai nuo dominuojančios etiologijos, patologijos pasireiškimo, regejjimo sunkumo ir regos praradimo trukmès [6]. Optinị neuritą pagal atsiradimo priežastị galima suskirstyti ị tipinị ir atipinį, kai tipinis siejamas su IS dèl demielinizacinių procesų galvos smegenyse, kurie sukelia aksonų netekimą. Atipinis susijęs su kitomis būklèmis: infekcijomis (pvz., Laimo liga), autoimuninėmis ligomis (pvz., sisteminė raudonoji vilkligè), paveldètomis optinèmis neuropatijomis, toksinèmis, maistinèmis (pvz., vitamino B12 trūkumas) ar vaistų sukeltomis neuropatijomis [4]. Tipinị ir atipinị ON veikia skirtingi predisponuojantys veiksniai, būdinga anamnezè bei jiems savita proceso pažeidimo lokalizacija. Pvz., tipinis regos nervo uždegimas yra būdingesnis $<50$ metų pacientams, pasireiškiantis ūmiu (poūmiu) vienpusiu regos netekimu ir skausmu, didejjančiu su akies judesiu. Atipinis būdingesnis $<12$ metų ir $>50$ metu žmonèms. Gali pasireikšti kaip staigus, vienpusis (abipusis) skausmas [7].

Klinika. Simptomiškai ON pasireiškia skausmu, kuris paprastai stiprejja judesių metu, taip pat vienpusiu regos praradimu [3]. Matymas lyg pro rūką ir dischromatopsija (dvigubi spalvų pakitimai, kai ūmioje fazèje sutrinka mėlynos ir geltonos spalvų juslé, o poūmèje - rausvos ir žalios) yra anksti pasireiškiantys ligos požymiai [4]. Regos aštrumas gali kisti nuo minimalių regejjimo pokyčių iki absoliutaus regos netekimo. Fototopsijos (šviesos žybsniai) gali būti dar vienas požymis, signalizuojantis apie regos nervo pokyčius [5]. Pasitaiko ir gylio pojūčio sutrikimas judantiems objektams, toks simptomas vadinamas Pulfricho fenomenu (PF). Tai iliuzinis suvokimas, kad objektas, judantis tiesiai išilgai 2-D plokštumos, vietoj to eina elipsine 3-D trajektorija [8]. Kitas regos nervo uždegimo požymis yra Unthoffo simptomas, kai pakilus kūno temperatūrai (po karšto dušo ar fizinès veiklos), regos atsikūrimo periodu pacientai skundžiasi trumpalaikiu ligos pablogėjimu [9]. Regos nervo uždegimo metu galimi centriniai bei periferiniai akipločio pakitimai. Pažymètina ir tai, kad periferiniai pakitimai, nors ir retesni, tačiau atsikuria žymiai greičiau, nei centriniai [5].

Diagnostika. Norint laiku ir tinkamai gydyti ON, svarbu greitai nustatyti šios ligos etiologiją, suprasti regos nervo uždegimo priežastị, gebėti ịvertinti specifinių simptomų pasireiškimą [6]. Nors tipiniam optiniam neuritui nustatyti dažnai užtenka tik klinikinių požymių, atipinio neurito atveju gali pasireikšti ir kitų ligų simptomai (pvz. akiduobės uždegimas) [3]. Tuomet tenka remtis ir instrumentinių tyrimų rodmenimis bei neurooftalmologiniu ištyrimu. Iprastai atliekami optinès koherentinès tomografijos (OKT), serologiniai tyrimai bei magnetinio rezonanso tyrimas (MRT) - viena tiksliausių priemonių regos nervo uždegimui diagnozuoti (95 proc. tikslumu nustatomas ON asmenims, kuriems maždaug per 20 dienų gresia regos praradimas). OKT yra tyrimas, tinkamas subtiliai optinio nervo ir tinklainès patologijai aptikti. Jo metu galima identifikuoti peripapiliarinio tinklainès nervinio skaidulų pluošto sluoksnio sustorejjimą, kuris dažnai aptinkamas optinio neurito metu. Kaip alternatyva šiam tyrimui taikoma ir OKT angiografija, kuri teikia informaciją apie tinklainès kraujagysles bei diagnostinę ir prognostinę informaciją pacientams su regos nervo uždegimu [6].

Gydymo galimybės. Gydymo pasirinkimas priklauso nuo etiologijos ir ligą sukèlusios priežasties. Gairès, kuriomis paremtas skirtingų ON tipų gydymas, sudarytos pagal atliktus tyrimus, įrodžiusius efektyviausias šios patologijos šalinimo priemones. Vienas jų - optinio neurito gydymo atsitiktinių imčių tyrimas (ONTT), kuriame dalyvavę pacientai su regos nervo uždegimu buvo stebèti 15 metų. Iki šių dienų šis didelès apimties tyrimas išlieka demielizuojančio optinio neurito gydymo pagrindu. Palyginti gydymo intraveniniu metilprednizolonu, peroraliniu prednizolonu ir peroraliniu placebu variantai privedè prie išvados, kad geriamasis prednizolonas nèra pranašesnis už placebą ir yra susijęs su padidejjusia rizika pasikartoti ON. Pasirinkimas pradèti gydymą intraveniniu metilprednizolonu lèmé greitesnị regos pagerẻjimą po 30 dienų. Vèliau atlikti mažesnés apimties tyrimai parodè panašius rezultatus: i/v steroidai lemia greitesni pasveikimą, tačiau nėra reikšmingi ilgalaikiam regos atsikūrimui [13]. Nepaisant šių rezultatų, vis dar nèra ịtikinamų ịrodymų, kad intraveniniai steroidai gerintų regejjimo rezultatus ir po 6 ménesių [14]. Remiantis atliktų tyrimų išvadomis, šiuo metu naudojamos gairès nurodo skirtingą preparatų pasirinkimą tipinio ir atipinio ON gydymui [3,5,10-12].

STAT4 vaidmuo ON patologijos metu. Vis daugiau mokslinių tyrimų krypčių veda ị ịvairių genetinių veiksnių bei jų poveikio organizmui paiešką. Šiandien žmogaus genome nustatyti 7 STAT (transkripcijos signalo keitikliai ir aktyvintojai) baltymų šeimos nariai: STAT1, STAT2, STAT3, STAT4, STAT5A, STAT5B, STAT6 [17]. Kaip pavadinimas ir nurodo, šie baltymai yra atsakingi už signalu perdavimą iš ląstelès membranos ị branduolị, taip suaktyvindami genų transkripciją. Kitaip tariant, jie lemia daugiafunkcini fiziologinių ląstelių procesų reguliavimą, kuris apima proliferaciją, diferenciaciją, apoptozę, angiogenę ir imuninès sistemos reguliavimą. Šie veiksniai, būdami aktyvūs, keliauja ị ląstelès branduolị, ten susiriša su DNR ir taip reguliuoja genų transkripciją, todèl ir vadinami transkripcijos signalo keitikliais [15]. Galimi pažeidimai, kurie lemia netinkamą STAT raišką, sąlygojančią îvairių piktybinių ląstelių transformacijas bei metastazes [16]. STAT3 ir STAT5 jau pripažinti onkogenais 
[18], o šiandien plačiau aptariamas STAT4 laikomas kaip imlus genas daugelio autoimuninių sutrikimų atvejais bei atlieka svarbų vaidmenị ịgimtų ir prisitaikančių imuninių ląstelių veikloje. Savyje talpindamas keletą pavienių nukleotidų polimorfizmų (VNP), siejamų su padidejusia autoimuninių sutrikimų rizika, pvz., sistemine raudonaja vilklige (SLE), reumatoidiniu artritu (RA) ir skydliaukès sutrikimais, STAT4 išlieka tyrimų objektu, siekiant išsiaiškinti daugelio autoimuninių ligų mechanizmus.

Aiškinantis, kokią itaką organizmui gali tureti ketvirtasis STAT baltymų šeimos atstovas, pasaulyje jau atlikta ịvairių tyrimų. Vienas jų yra atvejo kontrolès tyrimas, kuriuo siekta išsiaiškinti, ar STAT4 prisideda prie neuromielito optikos spektro sutrikimo (NMOSD) rizikos, kadangi baltymo ryšys su NMOSD sutrikimais išlieka neaiškus. Parinkti penki pavieniai nukleotidu polimorfizmai (VNP) atskleide, kad STAT4 polimorfizmai vis tik yra susiję su NMOSD rizikos padidejimu [19].

Kito tyrimo metu buvo siekiama rasti STAT4 ir reumatoidinio artrito bei sisteminès raudonosios vilkligès sąsajas. Išvados parodè, kad VNP buvo susijęs tiek su reumatoidinio artrito, tiek su sisteminès raudonosios vilkligès pasireiškimu [20]. STAT4 geno pasireiškimas siejamas taip pat ir su 1 tipo cukriniu diabetu (1 tipo CD). Atliktuose tyrimuose teigiama, kad europiečiams ir korejjiečiams nustatytas bendro STAT4 haplotipo ryšys su 1 tipo cukriniu diabetu (T1D) ir reumatoidiniu artritu, o išvadose skelbta, kad STAT4 aleliai ir tie patys haplotipai gali turetti įtakos autoimuninio tiroidito bei T1D vystymuisi [21]. Dar vienas tyrimas išskirste pacientus i ankstyvojo ir vèlyvojo laikotarpio pogrupius ir pateikè išvadas, kuriose nedideli aleliai vis tik atskleidè reikšmingą ryšį su 1 tipo $\mathrm{CD}$. Tai privedè prie rezultatų, kad STAT4 gali būti ne tik siejamas su šia liga, bet yra būdingas būtent ankstyvajam 1 tipo cukrinio diabeto vystymusi [22].

\section{Išvados}

1. Regos nervo uždegimas yra ịvairialypès etiologijos, savitos klinikos liga, dažnai siejama su gerai žinomomis priežastimis. Greitas patologijos diferencijavimas ir ankstyvas nustatymas yra pirmas žingsnis ị sẻkmingą ir teigiamą paciento ligos prognozę.

2. Nepaisant atliktų tyrimų, informacija apie genetinių veiksnių poveikį vis dar skurdi. Iš apžvelgtų tyrimų matome, kad egzistuoja ir genetine šios ligos predispozicija, siejama su baltymų transkripcijos signalo keitiklių ir aktyvintojų baltymų šeimos nariu STAT4.

\section{Literatūra}

1. Pukenytė R., Šustickas G., Ščerbak J., Aukštikalnis D., Ašoklis R. Regos nervo sužalojimas: literatūros apžvalga. Lietuvos chirurgija, 2011;9(1-2):18-24.

https://doi.org/10.15388/LietChirur.2011.1.2089

2. Dhillon N. Anatomy. In: Lalwani AK, editor. Current Diagnosis \& Treatment Otolaryngology. Head and Neck Surgery, 4e. New York: McGraw-Hill Education 2020.

3. Punytė V, Liutkevičienė R, Gelžinis A, Žemaitienè R. Optic neuritis. J Med Sci 2020;8(16):170-5.

4. Toosy AT, Mason DF, Miller DH. Optic neuritis. The Lancet Neurology 2014;13:83-99. https://doi.org/10.1016/S1474-4422(13)70259-X

5. Slavinskaitė A., Banevičius M., Kriaučiūnienė L., Zlatkutė E., Vilkevičiūtė A., Liutkevičienẻ R. Regos nervo neurito pagrindiniai diagnostikos ir gydymo principai. Neurologijos seminarai, 2016; 20(67):17-22.

6. Bennett JL. Optic Neuritis. Continuum (Minneap Minn) 2019;25(5):1236-1264.

https://doi.org/10.1212/CON.0000000000000768

7. Voss E, Raab P, Trebst C, Stangel M. Clinical approach to optic neuritis: Pitfalls, red flags and differential diagnosis. Therapeutic Advances in Neurological Disorders 2011; 4:123-34. https://doi.org/10.1177/1756285611398702

8. Sobhanian MJ, Agarwal R, Meltzer E, Kildebeck E, Frohman BS, Frohman AN, et al. Identification and treatment of the visual processing asymmetry in MS patients with optic neuritis: The Pulfrich phenomenon. J Neurol Sci 2018;387:60-9. https://doi.org/10.1016/j.jns.2018.01.029

9. Jain A, Rosso M, Santoro JD. Wilhelm Uhthoff and Uhthoff's phenomenon. Mult Scler J 2020;26(13):1790-6. https://doi.org/10.1177/1352458519881950

10. Mackay DD. Should patients with optic neuritis be treated with steroids? Current Opinion in Ophthalmology 2015;26(6):439-444. https://doi.org/10.1097/ICU.0000000000000197

11. Noseworthy JH, O'Brien PC, Petterson TM, Weis J, Stevens $\mathrm{L}$, Peterson WK, et al. A randomized trial of intravenous immunoglobulin in inflammatory demyelinating optic neuritis. Neurology 2001;56(11):1514-22. https://doi.org/10.1212/WNL.56.11.1514

12. Ruprecht K, Klinker E, Dintelmann T, Rieckmann P, Gold R. Plasma exchange for severe optic neuritis: Treatment of 10 patients. Neurology 2004;63: 1081-3. https://doi.org/10.1212/01.WNL.0000138437.99046.6B

13. Abel A, McClelland C, Lee MS. Critical review: Typical and atypical optic neuritis. Survey of Ophthalmology 2019;64:770-9. https://doi.org/10.1016/j.survophthal.2019.06.001

14. Gal RL, Vedula SS, Beck R. Corticosteroids for treating optic neuritis. Cochrane Database of Systematic Reviews. John Wiley and Sons Ltd 2015;2015.

https://doi.org/10.1002/14651858.CD001430.pub4

15. Verhoeven Y, Tilborghs S, Jacobs J, De Waele J, Quatannens D, Deben C, et al. The potential and controversy of targeting STAT family members in cancer. Seminars in Cancer Biology. 
Academic Press 2020;60:41-56.

https://doi.org/10.1016/j.semcancer.2019.10.002

16. Bowman T, Garcia R, Turkson J, Jove R. STATs in oncogenesis. Oncogene. Nature Publishing Group 2000;19:2474-88. https://doi.org/10.1038/sj.onc.1203527

17. Ihle JN. The Stat family in cytokine signaling. Current Opinion in Cell Biology. Elsevier Ltd 2001;13:211-7.

https://doi.org/10.1016/S0955-0674(00)00199-X

18. Calò V, Migliavacca M, Bazan V, Macaluso M, Buscemi M, Gebbia N, et al. STAT Proteins: From Normal Control of Cellular Events to Tumorigenesis. J Cell Physiol 2003;197:157-68. https://doi.org/10.1002/jcp.10364

19. Shi Z, Zhang Q, Chen H, Lian Z, Liu J, Feng H, et al. STAT4 Polymorphisms are Associated with Neuromyelitis Optica Spectrum Disorders. NeuroMolecular Med 2017;19(4):493500.

https://doi.org/10.1007/s12017-017-8463-9

20. Remmers EF, Plenge RM, Lee AT, Graham RR, Hom G, Behrens TW, et al. STAT4 and the Risk of Rheumatoid Arthritis and Systemic Lupus Erythematosus. N Engl J Med 2007;357(10):977-86.

https://doi.org/10.1056/NEJMoa073003

21. Bi C, Li B, Cheng Z, Hu Y, Fang Z, Zhai A. Association study of STAT4 polymorphisms and type 1 diabetes in Northeastern Chinese Han population. Tissue Antigens 2013; 81(3):137-40. https://doi.org/10.1111/tan.12057

22. Lee HS, Park H, Yang S, Kim D, Park Y. STAT4 polymorphism is associated with early-onset type 1 diabetes, but not with lateonset type 1 diabetes. In: Annals of the New York Academy of
Sciences. Blackwell Publishing Inc 2008:93-8.

https://doi.org/10.1196/annals.1447.013

\section{OPTIC NEURITIS AND ASSOCIATIONS OF STAT4 \\ G. Dubinskaitė, R. Liutkevičienè}

Keywords: optic nerve, etiology, symptoms, diagnostics, treatment, STAT4.

Summary

The optic nerve is the structure of white matter in the brain that connects the brain to the retina and performs the function of transmitting visual information. Anatomically, this structure can be divided into 4 segments: intraocular segment, intraorbital cavity, the part in the skull box and the part of the nerve in the bone canal. Often, the optic nerve can be exposed to a variety of environmental and genetic factors that can affect the onset of optic neuritis. Probably the best known and most common cause of inflammation is multiple sclerosis, where atypical inflammation is associated with other conditions such as infections, autoimmune diseases, toxic, nutritional or drug-induced neuropathies. Recently, a number of questions have been raised as to what are the genetic causes that may influence the onset of optic neuritis, as the effects of genetic factors still remain vague.

In this article we review the etiology, clinic, diagnostic and treatment possibilities of the optic nerve inflammation, the effect of the STAT4 gene on the occurrence of optic neuritis.

Correspondence to: g.dubinskaite@gmail.com

Gauta 2021-10-22 